\title{
Purification and characterization of a novel metalloprotease from fruiting bodies of Oudemansiella radicata
}

\author{
Xueran Geng ${ }^{1,2}$, Rigen Te², Guoting Tian³, Yongchang Zhao ${ }^{3}$, Liyan Zhao4, Hexiang Wang ${ }^{2 凶}$ \\ and Tzi Bun Ng ${ }^{5 \bowtie}$ \\ 'College of Food Science and Engineering, Shanxi Agricultural University, Taigu, Shanxi 030801, China; 2State Key Laboratory for Agrobiotech- \\ nology and Department of Microbiology, China Agricultural University, Beijing 100193, China; 31nstitute of Biotechnology and Germplasmic \\ Resource, Yunnan Academy of Agricultural Science, Kunming 650223, China; ${ }^{4}$ College of Food Science and Technology, Nanjing Agricultural \\ University, Weigang, Nanjing 210095, China; ${ }^{5}$ School of Biomedical Sciences, Faculty of Medicine, The Chinese University of Hong Kong, Shatin, \\ New Territories, Hong Kong, China
}

In this study, a 39-kDa metalloprotease was purified from a rare edible mushroom with health-promoting activities, Oudemansiella radicata, using a purification protocol which entailed anion exchange chromatography on DEAE-cellulose and Q-Sepharose columns and gel filtration by fast protein liquid chromatography on a Superdex 75 column. Some peptide sequences were obtained by LC-MS/MS analysis and one of the sequences, DAWIQADVNR, manifested $90 \%$ identity to Coprinopsis cinerea metalloprotease. The optimal reaction $\mathrm{pH}$ and temperature for Oudemansiella radicata protease were $\mathrm{pH} 7.0$ and $50^{\circ} \mathrm{C}$, respectively. The protease was purified 79-fold and demonstrated a specific protease activity of $2.42 \mathrm{U} / \mathrm{mg}$. The $K_{\mathrm{m}}$ of the purified protease for the casein substrate was $0.65 \mathrm{mg} / \mathrm{mL}$ at $\mathrm{pH} 7.0$ and $50^{\circ} \mathrm{C}$. The activity of the protease was inhibited by $\mathrm{Cd}^{2+}, \mathrm{Hg}^{2+}, \mathrm{Cu}^{2+}, \mathrm{Pb}^{2+}$ and $\mathrm{Fe}^{3+}$ ions, but was enhanced by $\mathrm{K}^{+}, \mathrm{Mn}^{2+}$ and $\mathrm{Fe}^{2+}$ ions. The marked suppression of the protease activity by EDTA indicates that the protease is a metalloprotease.

Key words: edible mushroom, Oudemansiella radicata, protease, purification

Received: 26 September, 2016; revised: 10 March, 2017; accepted: 08 May, 2017; available on-line: 08 September, 2017

e-mail: hxwang@cau.edu.cn (H.W.); b021770@mailserv.cuhk.edu. hk (T.B.N.)

Abbreviations: EDTA, ethylene diamine tetraacetic acid; FPLC, fast protein liquid chromatography; LC-MS/MS, liquid chromatographytandem mass spectrometry; $\mathrm{NaOAc}-\mathrm{HOAc}$, sodium acetate-acetic acid; NCBI, national center for biotechnology information; PMSF, phenylmethylsufonyl fluoride; SDS-PAGE, sodium dodecyl sulfatepolyacrylamide gel electrophoresis; TCA, trichloroacetic acid

\section{INTRODUCTION}

Mushrooms are abundant in bioactive compounds comprising proteases (Hu et al., 2012; Moon et al., 2014; Zheng et al., 2011), lectins (Wang et al., 2013; Xu et al., 2014; Zhang et al., 2014b), angiotensin I-converting enzyme inhibitory peptides (Geng et al., 2015; Kang et al., 2013; Lau et al., 2014; Mohamad Ansor et al., 2013), ribonucleases (Xu et al., 2013; Zhang et al., 2014a), acid phosphatases (Wannet et al., 2000; Zhang et al., 2013), laccases (Tian et al., 2012; Xu et al., 2015a; Xu et al., 2015b), antifungal proteins(Suzuki et al., 2011; Wong et al., 2010), and polysaccharides(Liu et al., 2014a; Ma et al., 2014; Mao et al., 2014; Zhu et al., 2014). Many of these mushroom proteins have potential applications or health-promoting activities in human (Liu et al., 2014b;
Wu et al., 2014). There are also many papers documenting that extracts and purified compounds from various edible mushrooms have significant anti-cancer properties, for example, Antrodia cinnamomea sulfated polysaccharide exhibited activity in suppressing growth and migration of lung cancer cells ( $\mathrm{Lu}$ et al., 2016), Pro4X, an extract of the edible Grifola frondosa mushroom, displayed anti-cancer activity and prevented oncogenesis in BABLc mice (Roldan-Deamicis et al., 2016). Recently, a serine protease $(\mathrm{AkP})$ from the Termitomyces clypeatus mushroom was effective in killing cancer cells by restoration of the p53 level and cleavage of surface proteoglycans (Majumder et al., 2016). Several mushroom proteases, including proteases from Amanita farinosa (Sun et al., 2011) and Lepista nuda (Wu et al., 2011), had also shown an antiproliferative activity on human hepatoma HepG2 cells. Proteases catalyze hydrolysis of the amide bond and regulate a myriad of physiological processes (Rao et al., 1998; Wolfe, 2009). Apart from physiological functions, proteases occupy a vital position with respect to their diverse applications in a variety of industries, encompassing the brewing, dairy, meat, detergent, leather, and photographic industries (Kalisz, 1988).

Oudemansiella radicata, an edible medicinal mushroom belonging to the Tricholomataceae family, inhabits the soil surface or rotten woods of the broad-leaved trees from summer to autumn (Lee, 1988). The literature on Oudemansiella radicata in general is not abundant. It has been reported that Oudemansiella radicata exhibited an outstanding therapeutic and inhibitory effect on sarcoma 180 and Erhrlich carcinoma, which is attributed to the important chemical compound, i.e. oudenone (Anke et al., 1979). In our preliminary experiment, the extract of Oudemansiella radicata fruiting bodies displayed a strong protease activity indicating the presence of a metalloprotease.

In order to obtain a valuable new protease, new naturally occurring species should be screened. Hence, in this investigation, a novel metalloprotease was purified from the Oudemansiella radicata mushroom.

\section{MATERIALS AND METHODS}

Materials. Fresh fruiting bodies of the Oudemansiella radicata mushroom were purchased from a market named Shuimuhua in the city of Kunming, Yunnan Province in southwest China. The fruiting bodies were then dried at room temperature. Q-Sepharose, Superdex 75 10/300 column and AKTA Purifier were all acquired from GE 
Healthcare (Sweden). DEAE-cellulose, casein sodium salt and protease inhibitors (Pepstatin A, Leupeptin and PMSF) were obtained from Sigma (USA). All other chemicals used were of analytical grade.

Purification of the protease. Dried fruiting bodies of the Oudemansiella radicata mushroom were soaked in distilled water $(\mathrm{w}: \mathrm{v}=1: 10)$ at $4^{\circ} \mathrm{C}$ for 3 hours, and then homogenized in a Waring blender. The homogenate was extracted at $4^{\circ} \mathrm{C}$ for 1 hour before centrifugation for $20 \mathrm{~min}$ at $9000 \mathrm{rpm}$ and $4^{\circ} \mathrm{C}$. After the $\mathrm{pH}$ of the supernatant had been adjusted, the supernatant was applied to a DEAE-cellulose column, which had previously been equilibrated with $10 \mathrm{mM} \mathrm{NaOAc-HOAc}$ buffer ( $\mathrm{pH}$ 5.6). After removal of the unadsorbed fraction D1, the adsorbed proteins were desorbed stepwise with $50 \mathrm{mM} \mathrm{NaCl}$ in the same buffer to yield fraction $\mathrm{D} 2$, and then with $100 \mathrm{mM} \mathrm{NaCl}, 300 \mathrm{mM} \mathrm{NaCl}$ and $1 \mathrm{M} \mathrm{NaCl}$ sequentially to yield fractions D3, D4 and D5, respectively. The highest protease activity was present in fraction D4. Fraction D4 was then subjected to ion exchange chromatography on a column of Q-Sepharose in $10 \mathrm{mM} \mathrm{NaOAc-HOAc}$ buffer (pH 5.2). Unadsorbed proteins were eluted with the starting buffer, and the adsorbed material was fractionated using a linear concentration gradient of $0-1 \mathrm{M} \mathrm{NaCl}$ in the same buffer. The active fraction Q1 was subsequently purified by fast protein liquid chromatography (FPLC) on a Superdex 75 HR 10/300 gel filtration column. Seven peaks, F1 to F7, were eluted with $150 \mathrm{mM} \mathrm{NH} \mathrm{NCO}_{3}$ buffer ( $\mathrm{pH}$ 8.5). The active fraction F3 was ultimately re-chromatographed on the Superdex 75 HR 10/300 gel filtration column. Only one peak (FP1), which represented purified protease, was obtained.

Assay for protease activity. Protease activity was determined using casein as the substrate following the method of Wang and $\mathrm{Ng}$ (2001) with slight modification. In brief, $20 \mu \mathrm{L}$ sample solution was incubated with $180 \mu \mathrm{L} 1 \mathrm{mg} / \mathrm{mL}$ casein (in distilled water) at $50^{\circ} \mathrm{C}$ for
$15 \mathrm{~min}$. Subsequently, the reaction was ended by adding $400 \mu \mathrm{L} \mathrm{5 \%}(\mathrm{w} / \mathrm{v})$ trichloroacetic acid (TCA). Then, the reaction mixture was centrifuged at $12000 \mathrm{rpm}$ for 5 min. The absorbance of the supernatant was read at $280 \mathrm{~nm}$ against water as blank. One unit of the enzyme activity was defined as an absorbance increase of 0.001 at $280 \mathrm{~nm}$ per milliliter of reaction mixture per minute under the experimental conditions.

SDS-polyacrylamide gel electrophoresis (SDSPAGE) and amino acid sequence analysis. The active peak (FP1) was subjected to SDS-PAGE for molecular mass determination in accordance with the procedure of Laemmli (Laemmli, 1970), using a 12\% resolving gel and $5 \%$ stacking gel. The bands were visualized after staining with Coomassie Brilliant blue. FPLC-gel filtration on a Superdex 75 column, which had been calibrated with molecular mass standards, was conducted to determine the molecular mass of the purified protease.

The band corresponding to the protease in SDSPAGE gel was destained, digested with trypsin, and then dissolved in $0.1 \%$ formic acid and $2 \%$ acetonitrile for liquid chromatography-tandem mass spectrometry (LCMS/MS) analysis using a LTQ-Orbitrap mass spectrometer (Thermo Electron, Bremen, Germany).

Determination of optimal $\mathrm{pH}$ and temperature for the isolated protease. In the assay for optimal $\mathrm{pH}$ value, a series of assay buffers covering a $\mathrm{pH}$ range of 2.5-9.0 (100 mM) were used, including citric acid-sodium citrate buffer ( $\mathrm{pH} 2.5$ and $\mathrm{pH} 3.0$ ), $\mathrm{NaOAc-HOAc}$ buffer $(\mathrm{pH} 4.0$ and $\mathrm{pH} 5.0), \mathrm{Na}_{2} \mathrm{HPO}_{4}-\mathrm{NaH}_{2} \mathrm{PO}_{4}$ buffer $(\mathrm{pH}$ 6.2) and Tris-HCl buffer ( $\mathrm{pH} 7.0,8.0$ and 9.0). Enzyme activity was determined using the above mentioned method.

To determine the optimal temperature for the protease, the standard protease assay mentioned above was conducted over a temperature range of $10-90^{\circ} \mathrm{C}$.

$\boldsymbol{K}_{\mathrm{m}}$ and $\boldsymbol{V}_{\max }$ values of the isolated protease. To obtain $K_{\mathrm{m}}$ and $V_{\max }$ of the purified protease toward the

Table 1. Yields and protease activities of various chromatographic fractions derived from Oudemansiella radicata fruiting body extract.

\begin{tabular}{|c|c|c|c|c|}
\hline Chromatographic fraction & $\begin{array}{l}\text { Total protein } \\
(\mathrm{mg})\end{array}$ & $\begin{array}{l}\text { Total protease activity } \\
\text { (U) }\end{array}$ & $\begin{array}{l}\text { Specific protease activity } \\
(\mathrm{U} / \mathrm{mg})\end{array}$ & Purification fold \\
\hline Crude extract & 36000 & 1100 & 0.03 & 1.00 \\
\hline D1 & 20000 & 66 & 0 & 0.11 \\
\hline D2 & 1500 & 40 & 0.03 & 0.87 \\
\hline D3 & 900 & 0 & 0 & 0 \\
\hline D4 & 5700 & 360 & 0.06 & 2.07 \\
\hline D5 & 7200 & 320 & 0.04 & 1.45 \\
\hline Q1 & 452 & 88 & 0.19 & 6.37 \\
\hline F1 & 19.50 & 2.40 & 0.12 & 4.03 \\
\hline $\mathrm{F} 2$ & 16.50 & 7.20 & 0.44 & 14.28 \\
\hline F3 & 12 & 9.60 & 0.80 & 26.18 \\
\hline F4 & 58.50 & 1.60 & 0.03 & 0.90 \\
\hline F5 & 40.50 & 0 & 0 & 0 \\
\hline F6 & 13.50 & 0 & 0 & 0 \\
\hline F7 & 9 & 0 & 0 & 0 \\
\hline FP1 & 0.66 & 1.60 & 2.42 & 79.34 \\
\hline
\end{tabular}


casein substrate, a series of casein solutions at different concentrations $(10,5,2.5,1.25$ and $0.625 \mathrm{mg} / \mathrm{mL})$ were mixed with the protease, followed by an assay of the enzymatic activity at $\mathrm{pH} 7.0$ and $50^{\circ} \mathrm{C}$. A double reciprocal (Lineweaver-Burk) plot of the reciprocal of reaction velocity against the reciprocal of substrate concentration was then constructed. The $K_{\mathrm{m}}$ and $V_{\max }$ values were calculated from the plot.

Effects of metal ions on the isolated protease. The effects of different metal ions on the protease were investigated by pre-incubating the compounds with the enzyme solution for $60 \mathrm{~min}$ at $4^{\circ} \mathrm{C}$ before the standard protease activity assay was performed. Chlorides of the following metals were used in the experiment at the final concentrations of $10,5,2.5$ and $1.25 \mathrm{mM} \mathrm{FeCl}_{3}, \mathrm{CuCl}_{2}$, $\mathrm{MnCl}_{2}, \mathrm{ZnCl}_{2}, \mathrm{HgCl}_{2}, \mathrm{MgCl}_{2}, \mathrm{PbCl}_{2}, \mathrm{AlCl}_{3}, \mathrm{CdCl}_{2}, \mathrm{KCl}$ and $\mathrm{FeCl}_{2}$.

Mechanistic class assay. The purified protease was exposed to the following inhibitors: phenyl methyl sulfonyl fluoride (PMSF), ethylene diamine tetraacetic acid (EDTA), pepstatin A and leupeptin at different concentrations $(0.04,0.2$ and $1 \mathrm{mM})$ to determine the mechanistic class that the protease belongs to. The activity was measured by using the standard assay protocol mentioned above and expressed as percentage of residual activity.

\section{RESULTS}

\section{Purification of Oudemansiella radicata protease}

Protease produced by Oudemansiella radicata was purified following a protocol that entailed two consecutive steps of ion exchange chromatography and two steps of gel filtration on a Superdex 75 column, resulting in

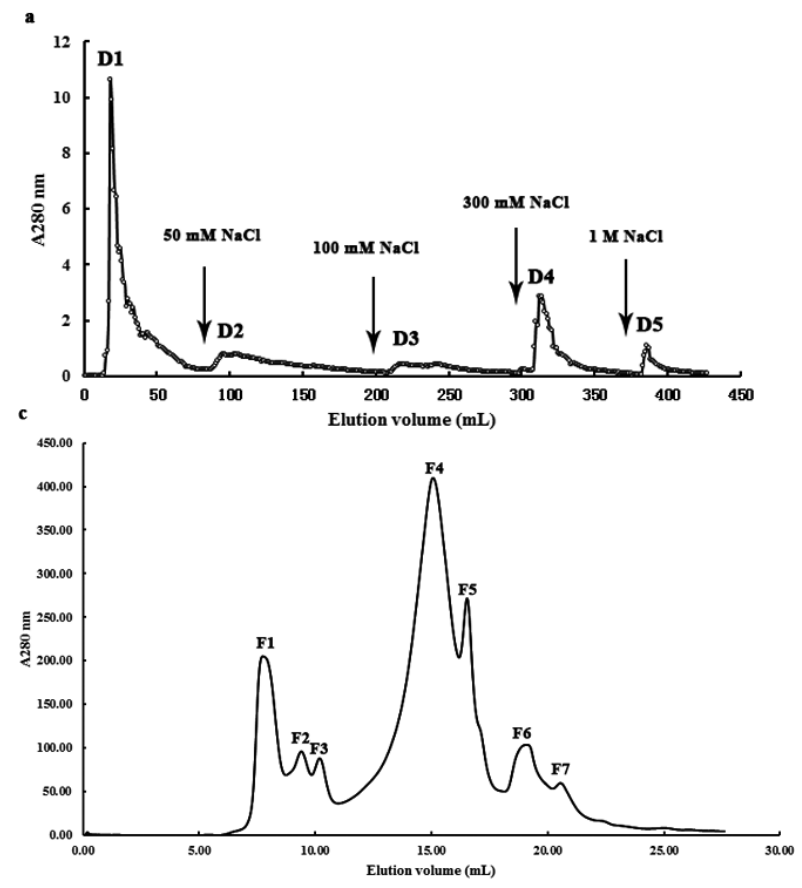

a specific protease activity of $2.42 \mathrm{U} / \mathrm{mg}$ and a purification factor of 79-fold (Table 1). The extract of Oudemansiella radicata was applied to a DEAE-cellulose ion exchange column. The enzyme extract was resolved into 5 fractions (D1-D5). Fractions D4 and D5, eluted with $300 \mathrm{mM}$ and $1 \mathrm{M} \mathrm{NaCl}$, respectively, demonstrated the protease activity (Table 1 and Fig. 1a). Since the purification fold of fraction D4 was much higher than that of fraction D5, fraction D4 was further purified on a QSepharose column and eluted with a linear gradient of 0-1 M NaCl. Protease activity was concentrated in fraction Q1 (Table 1 and Fig. 1b). Subsequently, fraction Q1 was resolved into 7 fractions (F1-F7) upon FPLC-gel filtration on Superdex 75. Fraction F3 exhibited a much higher protease activity than the other fractions (Table 1 and Fig. 1c). The active fraction F3 appeared as a single active peak, FP1, upon again FPLC-gel filtration on Superdex 75 (Fig. 1d).

\section{Determination of molecular mass and inner amino acid sequences}

The molecular mass of SP1 was $45.7 \mathrm{kDa}$, as judged from the comparison of its elution volume from the Superdex 75 column with those of molecular mass standards (Fig. 2a). In SDS-PAGE, fraction FP1 with enriched protease activity appeared as a single band with a molecular mass of $39 \mathrm{kDa}$ (Fig. 2b). This result was similar to that obtained from the Superdex 75 column. It indicated that the protease is a monomeric protein with a molecular mass of $39 \mathrm{kDa}$.

Five inner amino acid sequences of Oudemansiella radicata protease were obtained by LC-MS/MS: including AVVLGAAGGIGQPSALLLK, GFHLSSLVALAALLR, DAWIQADVNR, AQLGLGHSYSRAK and SSSIELINPKAESIR. It was found that peptide DAWIQADVNR had a $90 \%$ identity with metalloproteases from
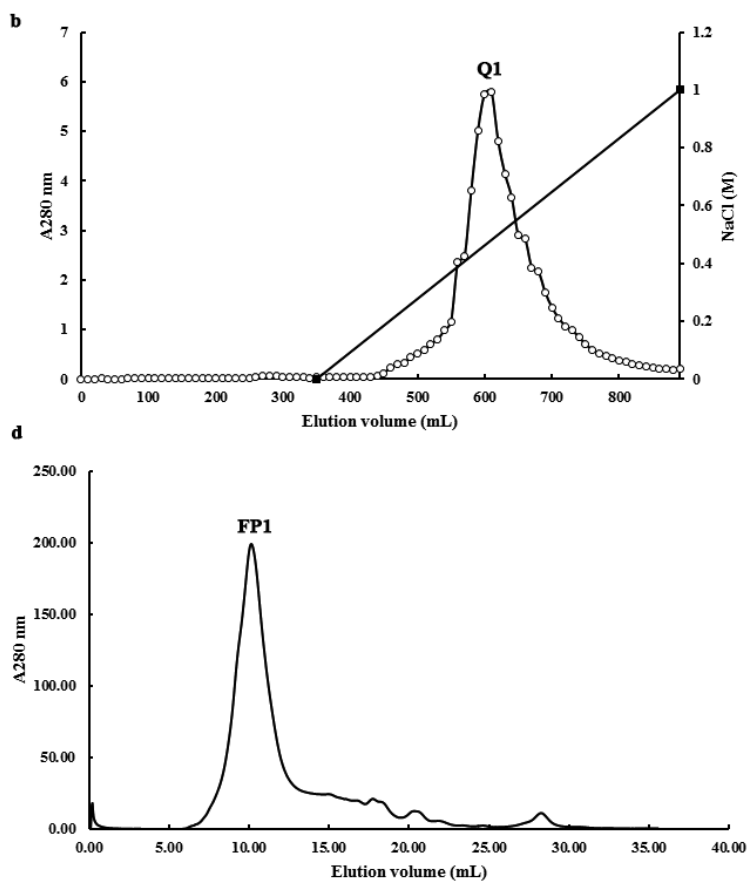

Figure 1. Elution profiles of the Oudemansiella radicata protease.

(a) Ion exchange chromatography on a DEAE-cellulose column. Fraction D4 was the fraction with the highest protease activity. (b) lon exchange chromatography of fraction D4 on a Q-sepharose column. Fraction Q1 was the fraction with protease activity. (c) Gel filtration of fraction Q1 on a Superdex 75 column by FPLC. Fraction F3 was the fraction with protease activity. (d) Gel filtration of fraction F3 on a Superdex 75 column by FPLC again. Fraction FP1 represents the purified Oudemansiella radicata protease. 


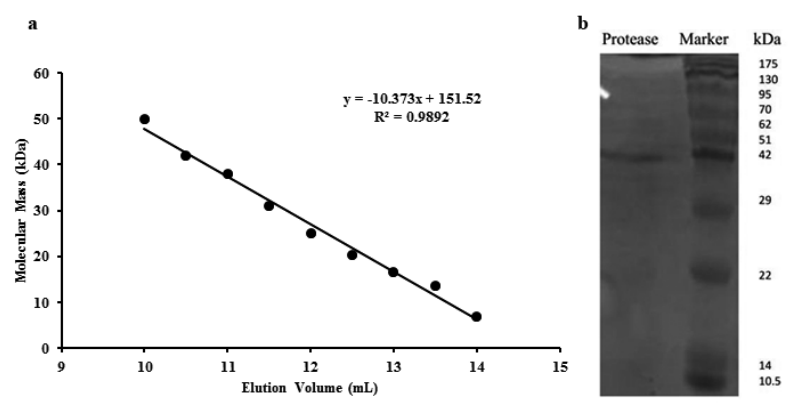

Figure 2. FPLC of molecular mass standards for calibrating Superdex 75 column and SDS-PAGE of fraction FP1 (purified protease) from Superdex 75 column.

(a) FPLC of molecular mass standards for calibrating Superdex 75 column. (b) SDS-PAGE of fraction FP1 (purified protease) from Superdex 75 column. The molecular mass of FP1 was $39 \mathrm{kDa}$.

Coprinopsis cinerea (accession number XP_001839300.2, P_001838846.1, XP_001835397.2) by NC̈BI database searching using BLASTT. It also shared 90\% identity with a metalloprotease from Punctularia strigosozonata HHB11173 SS5 (accession number XP_007380217.1).

\section{Characteristics of Oudemansiella radicata protease}

The protease exhibited an optimal $\mathrm{pH}$ at $\mathrm{pH} 7.0$ and an optimal temperature at $50^{\circ} \mathrm{C}$, respectively (Fig. $3 \mathrm{a}$ and Fig. 3b). The $\mathrm{pH}$ dependence of the protease activity toward casein is shown in Fig. 3a. When the $\mathrm{pH}$ was raised from 2.5 to 7.0 , the protease activity increased steadily. However, when the $\mathrm{pH}$ was raised beyond 7.0 a rapid decrease was observed. The protease activity vanished when the $\mathrm{pH}$ was increased up to 10 . It underwent a steady increase when the temperature was increased from 10 to $50^{\circ} \mathrm{C}$ and a decline in the enzyme activity when the temperature was raised further from 50 to $90^{\circ} \mathrm{C}$.

The $K_{\mathrm{m}}$ of purified $O$. radicata protease toward casein was $0.65 \mathrm{mg} / \mathrm{mL}$ at $\mathrm{pH} 7.0$ and $50^{\circ} \mathrm{C}$. The $V_{\max }$ was $125.85 \mu \mathrm{g} / \mathrm{mL} / \mathrm{min}$ (Fig. 4). The effects of various metal ions on the purified protease are shown in Table 2. The activity of purified protease was significantly depressed in the presence of cations such as $\mathrm{Fe}^{3+}, \mathrm{Cu}^{2+}, \mathrm{Cd}^{2+}, \mathrm{Hg}^{2+}$ and $\mathrm{Pb}^{2+}$ ions at the concentrations of $1.25-5.0 \mathrm{mM}$. The inhibitory activity of the protease was dose-dependent. The higher the concentrations of the metal ions: $\mathrm{Al}^{3+}$, $\mathrm{Zn}^{2+}$ and $\mathrm{Mn}^{2+}$ used, the stronger were the inhibitory effects on the activity of the purified protease. When

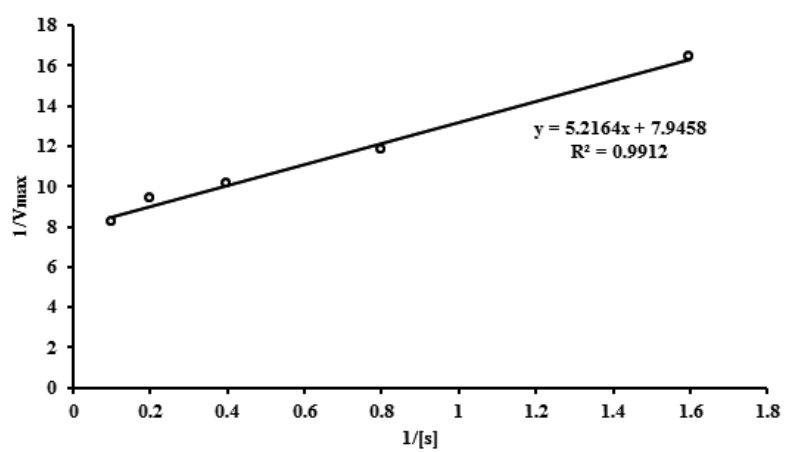

Figure 4. The Lineweaver-Burk plot for Oudemansiella radicata protease.

the concentration of the three metal ions was raised to $10 \mathrm{mM}$, only $37 \%, 17 \%$ and $63 \%$, respectively, of the protease activity were retained, while $\mathrm{Mn}^{2+}$ ions elicited slight enhancement of protease activity at the concentrations of $2.5 \mathrm{mM}$ and $1.25 \mathrm{mM}$. On the contrary, at the high concentration of $10 \mathrm{mM}, \mathrm{Fe}^{2+}$ ions demonstrated an enhancing action on the protease activity. The activity of the protease was potentiated by $\mathrm{K}^{+}$ions at all of the concentrations examined. Among the protease inhibitors tested, the activity of purified protease was adversely reduced by EDTA, but not affected to any major extent by PMSF, leupeptin and pepstatin A (Table 3), indicating that the enzyme belongs to the metalloprotease family.

\section{DISCUSSION}

In the present study, a novel metalloprotease was purified from fruiting bodies of the $O$. radicata mushroom, with two different chromatographic methods- anion exchange chromatography on DEAE-cellulose and anion exchange chromatography on Q-Sepharose. The $O$. radicata protease resembled other mushroom metalloproteases, such as Armillariella mellea, Pleurotus ostreatus and Tricholoma saponaceum metalloproteases, in that it was adsorbed on DEAE-cellulose and could be purified by anion exchange chromatography on DEAE-cellulose (Kim \& Kim, 1999, 2001; Shen et al., 2007).

When compared with other mushroom metalloproteases, $O$. radicata metalloprotease displays a number of remarkable differences in characteristics. The molecular mass of $O$. radicata protease $(39 \mathrm{kDa})$ was larger than those of the majority of mushroom metalloproteases (in
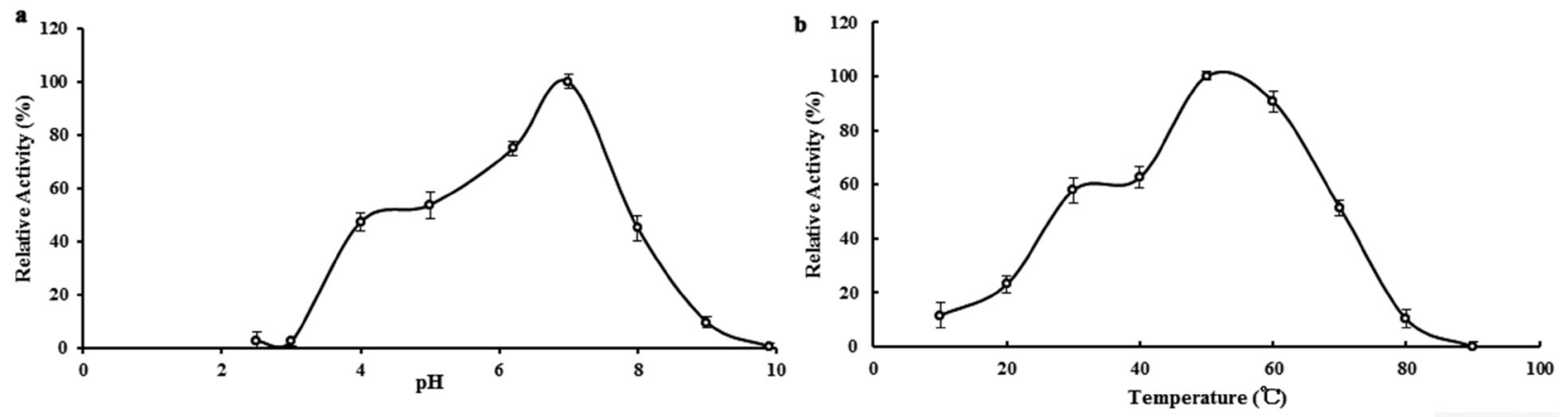

Figure 3. The optimal $\mathrm{pH}$ and temperature of Oudemansiella radicata protease.

(a) The optimal $\mathrm{pH}$ of Oudemansiella radicata protease was $\mathrm{pH}$ 7.0. The maximum value of the protease activity was set as $100 \%$. Results represent mean \pm S.D. $(n=3)$. (b) The optimal temperature of Oudemansiella radicata protease was $50^{\circ} \mathrm{C}$. The maximum value of the protease activity was set as $100 \%$. Results represent mean \pm S.D. $(n=3)$. 
Table 2. Effect of metal ions on the activity of Oudemansiella radicata protease.

\begin{tabular}{|c|c|c|c|c|}
\hline \multirow{2}{*}{ Metal ion concentration } & \multicolumn{4}{|c|}{ Relative protease activity (\%) } \\
\hline & $10 \mathrm{mmol} / \mathrm{L}$ & $5 \mathrm{mmol} / \mathrm{L}$ & $2.5 \mathrm{mmol} / \mathrm{L}$ & $1.25 \mathrm{mmol} / \mathrm{L}$ \\
\hline $\mathrm{Fe}^{2+}$ & $138 \pm 2.1$ & $82 \pm 3.6$ & $93 \pm 2.5$ & $97 \pm 1.4$ \\
\hline $\mathrm{K}^{+}$ & $147 \pm 1.7$ & $125 \pm 2.8$ & $111 \pm 3.7$ & $103 \pm 1.8$ \\
\hline $\mathrm{Mg}^{2+}$ & $95 \pm 4.5$ & $98 \pm 0.6$ & $125 \pm 2.6$ & $116 \pm 2.5$ \\
\hline $\mathrm{Mn}^{2+}$ & $63 \pm 0.9$ & $70 \pm 4.1$ & $115 \pm 3.3$ & $113 \pm 3.4$ \\
\hline $\mathrm{Zn}^{2+}$ & $17 \pm 1.3$ & $34 \pm 0.8$ & $65 \pm 0.7$ & $102 \pm 2.6$ \\
\hline $\mathrm{Al}^{3+}$ & $37 \pm 0.8$ & $45 \pm 1.3$ & $57 \pm 0.9$ & $72 \pm 2.8$ \\
\hline $\mathrm{Pb}^{2+}$ & $25 \pm 2.9$ & $28 \pm 0.9$ & $22 \pm 1.3$ & $58 \pm 0.5$ \\
\hline $\mathrm{Hg}^{2+}$ & $19 \pm 2.4$ & $4 \pm 0.2$ & $20 \pm 1.4$ & 0 \\
\hline $\mathrm{Cd}^{2+}$ & $4 \pm 0.3$ & $4 \pm 0.9$ & $9 \pm 1.3$ & $6 \pm 0.9$ \\
\hline $\mathrm{Cu}^{2+}$ & $15 \pm 3.2$ & 0 & $11 \pm 0.7$ & $5 \pm 1.2$ \\
\hline $\mathrm{Fe}^{3+}$ & 0 & 0 & 0 & $52 \pm 1.7$ \\
\hline
\end{tabular}

Results represent mean \pm S.D. $(n=3)$. The protease activity without metal ions added was set as $100 \%$.

the range from 18 to $32 \mathrm{kDa}$ ) (Kim \& Kim, 1999, 2001; Nonaka et al., 1995; Shen et al., 2007; Wu et al., 2011), and mushroom serine proteases (in the range from 15 to $35 \mathrm{kDa}$ ) (Burton et al., 1993; Cui et al., 2007; Sun et al., 2011; Zhang et al., 2010). However, it was lower than Hericium erinaceum fibirinolytic metalloprotease with a molecular mass of $51 \mathrm{kDa}$ (Choi et al., 2013) and much lower than other types of proteases, including a subtilisin-like protease from Pleurotus ostreatus $(75 \mathrm{kDa})$ (Palmieri et al., 2001), prolyl endopeptidases from Lyophyllum cinerascens (76 kDa) (Yoshimoto et al., 1988) and Agaricus bisporus (78 kDa) (Sattar et al., 1990) and an aminopeptidase from Lyophyllum cinerascens $(150 \mathrm{kDa})$ (Abdus Sattar et al., 1989).

The optimal $\mathrm{pH}$ for the activity of the reported mushroom metalloproteases ranged from $\mathrm{pH} 7.0$ to $\mathrm{pH}$ 8.0.

Table 3. Effect of inhibitors on the activity of Oudemansiella radicata protease.

\begin{tabular}{lcc}
\hline Inhibitors & $\begin{array}{c}\text { Concentration } \\
(\mathrm{mmol} / \mathrm{L})\end{array}$ & $\begin{array}{c}\text { Remaining protease activity } \\
(\%)\end{array}$ \\
\hline leupeptin & 0.04 & $90 \pm 3.8$ \\
& 0.2 & $87 \pm 2.2$ \\
\hline PMSF & 1 & $86 \pm 3.3$ \\
& 0.04 & $95 \pm 1.1$ \\
\hline & 0.2 & $100 \pm 2.1$ \\
\hline EDTA & 1 & $90 \pm 1.5$ \\
& 0.04 & $59 \pm 0.8$ \\
\hline & 0.2 & $36 \pm 2.4$ \\
\hline pepstatin A & 1 & $18 \pm 3.9$ \\
& 0.04 & $88 \pm 0.5$ \\
\hline
\end{tabular}

Results represent mean \pm S.D. $(n=3)$. The protease activity without any inhibitors added was set as $100 \%$.
The activity of Tricholoma saponaceum metalloprotease reached the maximum at $\mathrm{pH}$ 8.0. Both Lepista nuda metalloprotease and Armillariella mellea metalloprotease were most active at $\mathrm{pH} \mathrm{7.0,} \mathrm{which} \mathrm{was} \mathrm{consistent} \mathrm{with}$ the metalloprotease from O. radicata (Shen et al., 2007). The $O$. radicata metalloprotease manifested a temperature optimum at $50^{\circ} \mathrm{C}$, which was about quadrupled in comparison to its activity at $20^{\circ} \mathrm{C}$. However, its activity at $80^{\circ} \mathrm{C}$ was only about half of that at $20^{\circ} \mathrm{C}$, and its activity vanished at $90^{\circ} \mathrm{C}$. Thus, the protease had only moderate thermostability. The optimal temperature of the $O$. radicata metalloprotease was similar to those of its counterparts from Lepista nuda $\left(50^{\circ} \mathrm{C}\right)$, Tricholoma saponaceum $\left(55^{\circ} \mathrm{C}\right)$ and Armillariella mellea $\left(55^{\circ} \mathrm{C}\right)$, which were much higher than that of Pleurotus ostreatus metalloprease at $35^{\circ} \mathrm{C}$. The effects of metal ions toward protease activity varied considerably among different mushroom metalloproteases. The activity of Armillariella mellea metalloprotease was strongly inhibited by $\mathrm{Hg}^{2+}$ ions and the activity of Lepista nuda metalloprotease was reduced by $\mathrm{Cd}^{2+}$, $\mathrm{Hg}^{2+}$ and $\mathrm{Fe}^{3+}$ ions. In the presence of $\mathrm{Cu}^{2+}$ and $\mathrm{Hg}^{2+}$ ions, the activity of Tricholoma saponaceum metalloprotease totally disappeared. Many metal ions, including $\mathrm{Cd}^{2+}$, $\mathrm{Hg}^{2+}, \mathrm{Cu}^{2+}, \mathrm{Pb}^{2+}$ and $\mathrm{Fe}^{3+}$ ions, significantly inhibited the activity of $O$. radicata metalloprotease. It was seen that the activities of mushroom metalloproteases were greatly reduced by $\mathrm{Hg}^{2+}$ ions. On the other hand, $\mathrm{Mn}^{2+}, \mathrm{Zn}^{2+}$ and $\mathrm{Ca}^{2+}$ ions enhanced the protease activity of Grifola frondosa metalloprotease. $\mathrm{Mg}^{2+}, \mathrm{Zn}^{2+}$ and $\mathrm{Mo}^{2+}$ ions augmented the protease activity of Armillariella mellea metalloprotease. Proteases from Lepista nuda and O. radicata were activated by $\mathrm{Fe}^{2+}$ and $\mathrm{K}^{+}$ions, respectively (Kim \& Kim, 1999, 2001; Nonaka et al., 1995; Shen et al., 2007; Wu et al., 2011).

In addition, there are reports of several metalloproteases from other sources which had shown some similarity to the purified protease. The purified metalloprotease from Candida kefyr 41 PSB demonstrated a molecular mass of $43 \mathrm{kDa}$ (Yavuz et al., 2017) which was a little larger than that of $O$. radicata metalloprotease. Its optimal $\mathrm{pH}$ was the same as for the $O$. radicata metalloprotease. 
Its optimal temperature was $105^{\circ} \mathrm{C}$, much higher than the temperature optimum of purified $O$. radicata metalloprotease $\left(50^{\circ} \mathrm{C}\right)$. The $\mathrm{pH}$ and temperature optimum of a metalloprotease from Alternaria solani (Chandrasekaran et al., 2016) exhibited similiarity to the purified O. radicata metalloprotease. When compared with other metalloproteases, the $O$. radicata metalloprotease showed several notable differences in characteristics.

In summary, a metalloprotease with some distinctive characteristics was isolated from the wild mushroom $O$. radicata. To the best of our knowledge, this is one of the very few proteins reported on from this mushroom.

\section{Conflict of interest}

The authors declare no conflict of interest.

\section{Acknowledgements}

This work was financially supported by Special Fund for Agro-scientific Research in the Public Interest (No. 201303080) and collaborative project of Scientific Research and Graduate Training of Beijing Municipal Education Commission (No. 201502911110426). This work was also financially supported by the 2014 Shanxi Key Scientific and Technology of Coal Basic Research Project (FT2014-03) and The Collaborative Innovation Center Project of Loess Plateau Edible Fungus Quality Improvement in University of Shanxi Province.

\section{REFERENCES}

Abdus Sattar AK, Yoshimoto T, Tsuru D (1989) Lyophyllum cinerascens aminopeptidase: purification and enzymatic properties. Arch Biochem Biophys 274: 241-250

Anke T, Hecht H.J, Schramm G, Steglich W (1979) Antibiotics from basidiomycetes. IX. Oudemansin an antifungal antibiotic from Oudemansiella mucida (Schrader ex Fr.) Hoehnel (Agaricales). J Antibiot (Tokyo) 32: 1112-1117

Burton KS, Wood DA, Thurston CF, Barker PJ (1993) Purification and characterization of a serine proteinase from senescent sporophores of the commercial mushroom Agaricus bisporus. J Gen Microbiol 139 Pt 6: 1379-1386

Chandrasekaran M, Chandrasekar R, Chun SC, Sathiyabama M (2016) Isolation characterization and molecular three-dimensional structural predictions of metalloprotease from a phytopathogenic fungus Alternaria solani (Ell. and Mart.) Sor. J Biosci Bioeng 122: 131-139. http: //dx.doi.org/10.1016/j.jbiosc.2015.12.021

Choi BS, Sapkota K, Choi JH, Shin CH, Kim S, Kim SJ (2013) Herinase: a novel bi-functional fibrinolytic protease from the monkey head mushroom Hericium erinaceum. Appl Biochem Biotechnol 170: 609-622. http: //dx.doi.org/10.1007/s12010-013-0206-2

Cui L, Liu QH, Wang HX, Ng TB (2007) An alkaline protease from fresh fruiting bodies of the edible mushroom Pleurotus citrinopileatus. Appl Microbiol Biotechnol 75: 81-85. http: //dx.doi.org/10.1007/ s00253-006-0801-z

Geng X, Tian G, Zhang W, Zhao Y, Zhao L, Ryu M, Wang H, Ng TB (2015) Isolation of an angiotensin i-converting enzyme inhibitory protein with antihypertensive effect in spontaneously hypertensive rats from the edible wild mushroom Leucopaxillus tricolor. Molecules 20: 10141-10153. http: //dx.doi.org/10.3390/molecules200610141

Hu QX, Zhang GQ, Zhang RY, Hu DD, Wang HX, Ng TB (2012) A novel aspartic protease with $\mathrm{HIV}-1$ reverse transcriptase inhibitory activity from fresh fruiting bodies of the wild mushroom Xylaria bypoxylon. J Biomed Biotechnol 2012: 728975. http: //dx.doi. org $/ 10.1155 / 2012 / 728975$

Kalisz HM (1988) Microbial proteinases. Adv Biochem Eng Biotechnol 36: $1-65$

Kang MG, Kim YH, Bolormaa Z, Kim MK, Seo GS, Lee JS (2013) Characterization of an antihypertensive angiotensin I-converting enzyme inhibitory peptide from the edible mushroom Hypsiaygus marmoreus. Biomed Res Int 2013: 283964. http: //dx.doi. org $/ 10.1155 / 2013 / 283964$

Kim JH, Kim YS (1999) A fibrinolytic metalloprotease from the fruiting bodies of an edible mushroom Armillariella mellea. Biosci Biotechnol Biochem 63: 2130-2136

Kim JH, Kim YS (2001) Characterization of a metalloenzyme from a wild mushroom Tricholoma saponaceum. Biosci Biotechnol Biochem 65: 356-362
Laemmli UK (1970) Cleavage of structural proteins during the assembly of the head of bacteriophage T4. Nature 227: 680-685

Lau CC, Abdullah N, Shuib AS, Aminudin N (2014) Novel angiotensin I-converting enzyme inhibitory peptides derived from edible mushroom Agaricus bisporus (J.E. Lange) Imbach identified by LCMS/MS. Food Chem 148: 396-401. http: //dx.doi.org/10.1016/j. foodchem.2013.10.053

Lee JY (1988) Coloured Korean mushrooms. Academy Press Seoul Korea

Liu Q, Tian G, Yan H, Geng X, Cao Q, Wang H, Ng TB (2014a) Characterization of polysaccharides with antioxidant and hepatoprotective activities from the wild edible mushroom Russula vinosa Lindblad. I Agric Food Chem 62: 8858-8866. http: //dx.doi. org/10.1021/jf502632c

Liu XL, Zheng XQ, Qian PZ, Kopparapu NK, Deng YP, Nonaka M, Harada N (2014b) Purification and characterization of a novel fibrinolytic enzyme from culture supernatant of Pleurotus ostreatus. J Microbiol Biotechnol 24: 245-253

Lu MK, Lin TY, Chao CH, Hu CH, Hsu HY (2016) Molecular mechanism of Antrodia cinnamomea sulfated polysaccharide on the suppression of lung cancer cell growth and migration via induction of transforming growth factor beta receptor degradation. Int J Biol Macromol. http: //dx.doi.org/10.1016/j.ijbiomac.2016.11.004

Ma X, Zhou F, Chen Y, Zhang Y, Hou L, Cao X, Wang C (2014) A polysaccharide from Grifola frondosa relieves insulin resistance of HepG2 cell by Akt-GSK-3 pathway. Glycoconj J 31: 355-363. http: //dx.doi.org/10.1007/s10719-014-9526-x

Majumder R, Banik SP, Khowala S (2016) AkP from mushroom Termitomyces clypeatus is a proteoglycan specific protease with apoptotic effect on HepG2. Int J Biol Macromol 91: 198-207. http: // dx.doi.org/10.1016/j.ijbiomac.2016.05.034

Mao G, Feng W, Xiao H, Zhao T, Li F, Zou Y, Ren Y, Zhu Y, Yang L, Wu X (2014) Purification characterization and antioxidant activities of selenium-containing proteins and polysaccharides in royal sun mushroom Agaricus brasiliensis (Higher Basidiomycetes). Int J Med Mushrooms 16: 463-475

Mohamad Ansor N, Abdullah N, Aminudin N (2013) Anti-angiotensin converting enzyme (ACE) proteins from mycelia of Ganoderma lucidum (Curtis) P. Karst. BMC Complement Altern Med 13: 256. http: //dx.doi.org/10.1186/1472-6882-13-256

Moon SM, Kim JS, Kim HJ, Choi MS, Park BR, Kim SG, Ahn H, Chun HS, Shin YK, Kim JJ, Kim DK, Lee SY, Seo YW, Kim YH, Kim CS (2014) Purification and characterization of a novel fibrinolytic alpha chymotrypsin like serine metalloprotease from the edible mushroom Lyophyllum shimeji. J Biosci Bioeng 117: 544-550. https://doi.org/10.1016/j.jbiosc.2013.10.019

Nonaka T, Ishikawa $\mathrm{H}$, Tsumuraya $\mathrm{Y}$, Hashimoto $\mathrm{Y}$, Dohmae $\mathrm{N}$ (1995) Characterization of a thermostable lysine-specific metalloendopeptidase from the fruiting bodies of a basidiomycete Grifola frondosa. J Biochem 118: 1014-1020

Palmieri G, Bianco C, Cennamo G, Giardina P, Marino G, Monti M, Sannia G (2001) Purification characterization and functional role of a novel extracellular protease from Pleurotus ostreatus. Appl Environ Microbiol 67: 2754-2759. http: //dx.doi.org/10.1128/aem.67.6.27542759.2001

Rao MB, Tanksale AM, Ghatge MS, Deshpande VV (1998) Molecular and biotechnological aspects of microbial proteases. Microbiol Mol Biol Rev 62: 597-635

Roldan-Deamicis A, Alonso E, Brie B, Braico DA, Balogh GA (2016) Maitake Pro4X has anti-cancer activity and prevents oncogenesis in BALBc mice. Cancer Med 5: 2427-2441. http: //dx.doi.org/10.1002/ cam4.744

Sattar AK, Yamamoto N, Yoshimoto T, Tsuru D (1990) Purification and characterization of an extracellular prolyl endopeptidase from Agaricus bisporus. J Biochem 107: 256-261

Shen MH, Kim JS, Sapkota K, Park SE, Choi BS, Kim S, Lee HH, Kim CS, Chun HS, Ryoo CI, Kim SJ (2007) Purification characterization and cloning of fibrinolytic metalloprotease from Pleurotus ostreatus mycelia. J Microbiol Biotechnol 17: 1271-1283

Sun J, Zhao Y, Chai H, Wang H, Ng TB (2011) A novel alkaline protease with antiproliferative activity from fresh fruiting bodies of the toxic wild mushroom Amanita farinosa. Acta Biochim Pol 58: $567-572$

Suzuki T, Umehara K, Tashiro A, Kobayashi Y, Dohra H, Hirai H, Kawagishi $H$ (2011) An antifungal protein from the culinarymedicinal beech mushroom Hypsiaygus marmoreus (Peck) Bigel (Agaricomycetideae). Int J Med Mushrooms 13: 27-31

Tian GT, Zhang GQ, Wang HX, Ng TB (2012) Purification and characterization of a novel laccase from the mushroom Pleurotus nebrodensis. Acta Biochim Pol 59: 407-412

Wang H, Ng TB (2001) Pleureryn a novel protease from fresh fruiting bodies of the edible mushroom Pleurotus eryngii. Biochem Biophys Res Commun 289: 750-755. http: //dx.doi.org/10.1006/bbrc.2001.6037

Wang S.X, Zhang GQ, Zhao S, Xu F, Zhou Y, Li Geng X, Liu Y, Wang HX (2013) Purification and characterization of a novel lectin with antiphytovirus activities from the wild mushroom Paxillus involutus. Protein Pept Lett 20: 767-774 
Wannet WJ, Wassenaar RW, Jorissen HJ, van der Drift C, Op den Camp HJ (2000) Purification and characterization of an acid phosphatase from the commercial mushroom Agaricus bisporus. Antonie Van Leeuwenboek 77: 215-222

Wolfe MS (2009) Intramembrane-cleaving proteases. J Biol Chem 284: 13969-13973. http: //dx.doi.org/10.1074/jbc.R800039200

Wong JH, Ng TB, Cheung RC, Ye XJ, Wang HX, Lam SK, Lin P, Chan YS, Fang EF, Ngai PH, Xia LX, Ye XY, Jiang Y, Liu F (2010) Proteins with antifungal properties and other medicinal applications from plants and mushrooms. Appl Microbiol Biotechnol 87: 1221-1235. http: //dx.doi.org/10.1007/s00253-010-2690-4

Wu X, Huang C, Chen Q, Wang H, Zhang J (2014) A novel laccase with inhibitory activity towards HIV-I reverse transcriptase and antiproliferative effects on tumor cells from the fermentation broth of mushroom Pleurotus cornucopiae. Biomed Chromatogr 28: 548-553. http: //dx.doi.org/10.1002/bmc.3068

Wu YY, Wang HX, Ng TB (2011) A novel metalloprotease from the wild basidiomycete mushroom Lepista nuda. I Microbiol Biotechnol 21: 256-262

Xu LJ, Chen QJ, Wang HX, Zhang GQ (2013) Purification and characterization of a ribonuclease from the wild edible mushroom Armillaria luteo-virens. Indian J Biochem Biophys 50: 196-201

Xu CJ, Wang YX, Niu BN, Liu B, Li YB, Wang XM, Lu SL (2014) Isolation and characterization of a novel lectin with mitogenic activity from Pleurotus ferulae. Pak J Pharm Sci 27: 983-989

Xu L, Zhu M, Chen X, Wang H, Zhang G (2015) A novel laccase from fresh fruiting bodies of the wild medicinal mushroom Tricholoma matsutake. Acta Biochim Pol 62: 35-40. http://dx.doi. org/10.18388/abp.2014_713

Xu Y, Lu Y, Zhang R, Wang H, Liu Q (2016) Characterization of a novel laccase purified from the fungus Hobenbuebelia serotina and its decolourisation of dyes. Acta Biochim Pol 63: 273-279. http://dx.doi. org/10.18388/abp.2015_1091
Yavuz S, Kocabay S, Cetinkaya S, Akkaya B, Akkaya R, Yenidunya AF, Bakici MZ (2017) Production purification and characterization of metalloprotease from Candida kefyr 41 PSB. Int J Biol Macromol 94: 106-113. http: //dx.doi.org/10.1016/j.ijbiomac.2016.10.006

Yoshimoto T, Sattar AK, Hirose W, Tsuru D (1988) Studies on prolyl endopeptidase from shakashimeji (Lyophyllum cinerascens): purification and enzymatic properties. J Biochem 104: 622-627

Zhang GQ, Chen QJ, Sun J, Wang HX, Han CH (2013) Purification and characterization of a novel acid phosphatase from the split gill mushroom Schizopbyllum commune. J Basic Microbiol 53: 868-875. http: //dx.doi.org/10.1002/jobm.201200218

Zhang R, Zhao L, Wang H, Ng TB (2014a) A novel ribonuclease with antiproliferative activity toward leukemia and lymphoma cells and HIV-1 reverse transcriptase inhibitory activity from the mushroom Hohenbuehelia serotina. Int J Mol Med 33: 209-214. http: //dx.doi. org/10.3892/ijmm.2013.1553

Zhang W, Tian G, Geng X, Zhao Y, Ng TB, Zhao L, Wang H (2014b) Isolation and characterization of a novel lectin from the edible mushroom Stropharia rugosoannulata. Molecules 19: 19880-19891. http: //dx.doi.org/10.3390/molecules191219880

Zhang X, Liu Q, Zhang G, Wang H, Ng TB (2010) Purification and molecular cloning of a serine protease from the mushroom Hypsizigus marmoreus. Process Biochemistry 45: 724-730. http: //dx.doi. org/10.1016/j.procbio.2010.01.009

Zheng S, Wang H, Zhang G (2011) A novel alkaline protease from wild edible mushroom Termitomyces albuminosus. Acta Biocbim Pol 58: 269-273

Zhu L, Tang Q, Zhou S, Liu Y, Zhang Z, Gao X, Wang S, Wang $Z$ (2014) Isolation and purification of a polysaccharide from the caterpillar medicinal mushroom Cordyceps militaris (Ascomycetes) fruit bodies and its immunomodulation of RAW 264.7 macrophages. Int J Med Mushrooms 16: 247-257 